\title{
Zinc metabolism in pregnant and lactating rats and the effect of varying iron: $\mathrm{Zn}$ in the diet
}

\author{
By SUSAN J. FAIRWEATHER-TAIT AND A. J. A. WRIGHT \\ AFRC Food Research Institute, Colney Lane, Norwich NR4 7UA
}

AND CHRISTINE M. WILLIAMS

North East Surrey College of Technology, Reigate Road, Ewell, Surrey KTI7 3DS

\section{(Received 10 November 1983-Accepted 4 April 1984)}

1. Pregnant rats were given control (46 mg iron $/ \mathrm{kg}, 61 \mathrm{mg} \mathrm{zinc} / \mathrm{kg})$, low-Zn (6.9 mg $\mathrm{Zn} / \mathrm{kg}$ ) or low-Zn plus $\mathrm{Fe}$ (168 $\mathrm{mg} \mathrm{Fe} / \mathrm{kg}$ ) diets from day 1 of pregnancy. The animals were allowed to give birth and parturition times recorded. Exactly $24 \mathrm{~h}$ after the end of parturition the pups were killed and analysed for water, fat, protein, Fe and $\mathrm{Zn}$ contents and the mothers' haemoglobin ( $\mathrm{Hb}$ ) and packed cell volume (PCV) were measured.

2. There were no differences in weight gain or food intakes throughout pregnancy. Parturition times were similar (mean time 123 (SE 15) min) and there were no differences in the number of pups born. Protein, water and fat contents of the pups were similar but the low-Zn Fe-supplemented group had higher pup Fe than the low-Zn unsupplemented group, and the control group had higher pup $\mathrm{Zn}$ than both the low-Zn groups. The low- $\mathrm{Zn}$ groups had a greater incidence of haemorrhaged or deformed pups, or both, than the controls.

3. Pregnant rats were given diets of adequate $\mathrm{Zn}$ level $(40 \mathrm{mg} / \mathrm{kg})$ but with varying $\mathrm{Fe}: \mathrm{Zn}(0 \cdot 8,1 \cdot 7,2 \cdot 9,3 \cdot 7)$. $\mathrm{Zn}$ retention from the diet was measured using ${ }^{65} \mathrm{Zn}$ as an extrinsic label on days 3,10 and 17 of pregnancy with a whole-body gamma-counter. A group of non-pregnant rats was also included as controls. The ${ }^{65} \mathrm{Zn}$ content of mothers and pups was measured $24-48 \mathrm{~h}$ after birth and at 14, 21 and $24 \mathrm{~d}$ of age.

4. In all groups $\mathrm{Zn}$ retention was highest from the first meal, fell in the second meal and then rose in the third meal of the pregnant but not the non-pregnant rats. There were no differences between the groups given diets of varying $\mathrm{Fe}: \mathrm{Zn}$ level. Approximately $25 \%$ of the ${ }^{65} \mathrm{Zn}$ was transferred from the mothers to the pups by the time they were $48 \mathrm{~h}$ old, and a further $17 \%$ during the first $14 \mathrm{~d}$ of lactation. The pup ${ }^{65} \mathrm{Zn}$ content did not significantly increase after the first $20 \mathrm{~d}$ of lactation but the maternal ${ }^{65} \mathrm{Zn}$ level continued to fall gradually.

An interaction between dietary iron and zinc has been reported (Meadows et al. 1981; Solomons et al. 1983) such that at dietary $\mathrm{Fe}: \mathrm{Zn}$ levels above $2: 1$ apparent $\mathrm{Zn}$ absorption is reduced. This might have important consequences for pregnant women on a marginal-Zn diet given $\mathrm{Fe}$ supplements since increased $\mathrm{Fe}$ intake could ultimately reduce live birth weight by adverse effects on fetal $\mathrm{Zn}$ uptake (Williams et al. 1973). We have shown (Fairweather-Tait et al. 1984) that $\mathrm{Fe}$ supplements do not affect the weight or $\mathrm{Zn}$ content of rat fetuses at $21 \mathrm{~d}$ gestation from mothers given adequate $(60 \mathrm{mg} / \mathrm{kg})$ - or low $(7 \mathrm{mg} / \mathrm{kg})-\mathrm{Zn}$ diets. The work described in the present study is an extension of this work whereby the mothers were allowed to go to full term ( $22 \mathrm{~d}$ ) and the pups taken for analysis $24 \mathrm{~h}$ after the end of delivery. Following this work a second study was carried out in which $\mathrm{Fe}-\mathrm{Zn}$ interactions were investigated in diets of adequate $\mathrm{Zn}$ level $(40 \mathrm{mg} / \mathrm{kg})$ at various $\mathrm{Fe}: \mathrm{Zn}$ levels $(0 \cdot 8-3 \cdot 7)$. In this instance the retention of $\mathrm{Zn}$ from the diet was measured in a whole body gamma-counter using ${ }^{65} \mathrm{Zn}$ as an extrinsic label at the beginning of each trimester of pregnancy. The transfer of ${ }^{65} \mathrm{Zn}$ to the pups was measured at birth and 14,21 and $24 \mathrm{~d}$ later to see if $\mathrm{Fe}: \mathrm{Zn}$ in the diet had any effect on lactational transfer of $\mathrm{Zn}$. 
MATERIALS AND METHODS

Animals

In both experiments, 100 adult female Wistar rats were given a control, semi-synthetic diet for $10 \mathrm{~d}$ and then mated with adult male Wistars overnight in plastic and stainless-steel cages with grid bottoms. The occurrence of mating was verified by the presence of a mating plug the following morning and this was taken as day 1 of pregnancy. The pregnant females were caged separately and given the experimental diets $a d l i b$. They were weighed regularly and food intakes were measured throughout pregnancy.

\section{Expt 1}

The animals were divided into three groups: group 1 ( $n$ 11), control diet (Table 1); group 2 ( $n$ 12), low-Zn diet; group 3 ( $n$ 13), low-Zn diet plus added Fe. The low-Zn diet was made by omitting the zinc carbonate from the mineral mix and the low-Zn plus Fe made by adding extra ferrous sulphate $(0.72$ instead of $0.144 \mathrm{~g} / \mathrm{kg})$. At $21 \mathrm{~d}$ after mating a $24 \mathrm{~h}$ watch was kept on the mothers and the parturition time noted. The number of pups born live or dead was recorded. Exactly $24 \mathrm{~h}$ later maternal haemoglobin (Hb) and packed cell volume (PCV) were measured by anaesthetizing the mothers under diethyl ether and taking blood from the tail. The mothers and pups were then weighed and killed under carbon dioxide. Each litter was analysed for water, fat, protein, $\mathrm{Fe}$ and $\mathrm{Zn}$ contents.

\section{Expt 2}

The animals were divided into four groups and given diets of similar $\mathrm{Zn}$ content $(40 \mathrm{mg} / \mathrm{kg}$ ), but varying $\mathrm{Fe}$ levels $(32,70,115,148 \mathrm{mg} / \mathrm{kg})$ achieved by adjusting the amount of $\mathrm{FeSO}_{4}$ in the mineral mix, based on the control diet (Table 1). A few non-pregnant animals were included in each group to see the effects of pregnancy as opposed to diet on $\mathrm{Zn}$ metabolism.

At $48 \mathrm{~h}$ after mating the rats were fasted overnight and ${ }^{65} \mathrm{Zn}$ in $5 \mathrm{~g}$ of their diet was administered for the measurement of day $3 \mathrm{Zn}$ retention. The same measurement was made on days 10 and 17 of pregnancy. On each day of investigation, animals were given $5 \mathrm{~g}$ of their usual diet made to a paste with distilled water and extrinsically labelled with about $0.4 \mu \mathrm{Ci}^{65} \mathrm{Zn}\left(\mathrm{ZnCl}_{2}\right.$, carrier-free; Amersham International, Amersham, Bucks). Immediately after consuming the meal they were counted in a whole-body gamma-counter (Nuclear Enterprises, Edinburgh) to measure the ${ }^{65} \mathrm{Zn}$ content. Animals were only included in the results if they had consumed at least three-quarters of the labelled meal. The rats were given free access to the diet no sooner than $3 \mathrm{~h}$ after consuming the test meal. Each animal was counted daily in the whole-body counter to monitor ${ }^{65} \mathrm{Zn}$ content. By the 4 th day following the ${ }^{65} \mathrm{Zn}$ test meal all the unabsorbed ${ }^{65} \mathrm{Zn}$ had been excreted in the faeces. The measurement on this day was therefore taken to represent the amount of $\mathrm{Zn}$ retained from the test meal. At $2 \mathrm{~d}$ before parturition the animals were transferred to plastic and stainless-steel cages with solid bottoms. Within $48 \mathrm{~h}$ of birth half the mothers in each group (and their litters) were counted separately in the whole-body counter. The mothers were killed and the pups weighed and killed. The remaining animals were maintained on the same diets and counted $14 \mathrm{~d}$ after birth. Three animals from each group were then randomly selected and maintained on the same diets and both mothers and litters counted 21 and $24 \mathrm{~d}$ after birth.

\section{$\mathrm{Hb}$ and $\mathrm{PCV}$}

$\mathrm{Hb}$ was determined on freely-flowing blood from the tail vein using an $\mathrm{AO}$ haemoglobinometer (American Optical Corporation, Buffalo, New York). PCV was measured using the microhaematocrit technique. 
Table 1. Composition of control diet $(\mathrm{g} / \mathrm{kg})$

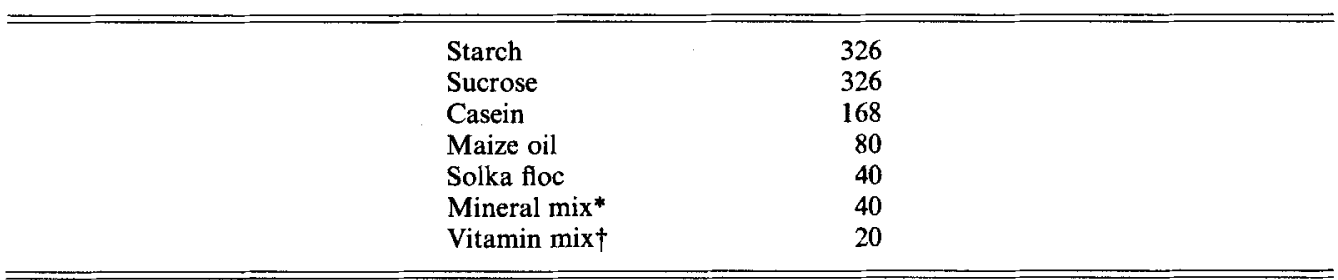

* Mineral mix (g/kg diet): $\mathrm{CaHPO}_{4} 13 \cdot 0, \mathrm{CaCO}_{3} 8 \cdot 2, \mathrm{KCl} 7 \cdot 03, \mathrm{Na}_{2} \mathrm{HPO}_{4} 7 \cdot 4, \mathrm{MgSO}_{4}, \mathrm{H}_{2} \mathrm{O} 4 \cdot 0, \mathrm{MnSO}_{4}, \mathrm{H}_{2} \mathrm{O}$ $0 \cdot 18, \mathrm{ZnCO}_{3} 0 \cdot 10, \mathrm{FeSO}_{4} \cdot 7 \mathrm{H}_{2} \mathrm{O} 0 \cdot 144, \mathrm{CuSO}_{4} 0 \cdot 015, \mathrm{KIO}_{3} 0 \cdot 001$.

$\dagger$ Vitamin mix (mg/kg diet): nicotinic acid 60, cyanocobalamin in mannitol 50, calcium-D-pantothenate 40, thiamin hydrochloride 10 , riboflavin 10 , pyridoxine 10 , pteroylmonoglutamic acid 5 , D-biotin 1 , menadione 1 , Rovimix E50 (Roche) 150, Rovimix A500 (Roche) 25, Rovimix D 500 (Roche) 15, choline bitartrate 1800.

\section{Analysis of pups}

The pups were analysed collectively within litters. Weighed, freeze-dried carcasses were ground in a Moulinex coffee grinder with stainless-steel blades and samples taken for fat analysis by Soxhlet estimation, for protein determination (Lowry et al. 1951) and for dry ashing. The $\mathrm{Zn}$ and $\mathrm{Fe}$ contents of dry-ashed samples were estimated by flame atomicabsorption spectrophotometry (PU9000 AAS; Pye Unicam Ltd, Cambridge).

\section{Whole-body gamma counting}

Animals were counted in a whole-body gamma-counter as previously described (FairweatherTait \& Wright, 1984). Results are expressed as ${ }^{65} \mathrm{Zn}$ content $4 \mathrm{~d}$ after test meal per ${ }^{65} \mathrm{Zn}$ content on day of test meal, corrected for both background and decay. It was assumed that all the unabsorbed ${ }^{65} \mathrm{Zn}$ would have been excreted within $4 \mathrm{~d}$ of the test meal, which was confirmed by the fact that the total body ${ }^{65} \mathrm{Zn}$ content fell sharply in the first $2 \mathrm{~d}$ but then levelled out.

\section{Statistical analysis}

Differences between groups in the measured variables were tested for significance by analysis of variance. First, Bartlett's test for variance heterogeneity was used to identify those variables whose variances differ between groups. For these variables an approximate $F$ test allowing for differing variances was used (Snedecor, 1957). For the remaining variables, the standard $F$ test assuming homogenous variance over groups was used. Where the $F$ test showed a treatment effect in the Expt 1 values, differences between each pair of groups were examined using $t$ tests. In Expt 2 the variances were found to be homogenous, and a two-way analysis of variance tested for effects of diet, pregnancy and time; $t$ tests assessed differences between particular pairs of means. The transfer of ${ }^{65} \mathrm{Zn}$ from mothers to litters was displayed as a scatter-plot, and the effect of diet tested by one-way analysis of variance at each time point (variance was homogeneous over dietary groups but not over time).

\section{RESULTS \\ Expt 1}

The number of rats successfully mated was eleven in group 1, twelve in group 2 and thirteen in group 3. There were no differences between the groups in weight at day 21 of pregnancy or in food intakes during pregnancy. The $\mathrm{Fe}(\mathrm{mg} / \mathrm{kg})$ and $\mathrm{Zn}(\mathrm{mg} / \mathrm{kg})$ contents of the diets 
Table 2. Expt 1. Parturition times (min), numbers of pups born, mean live pup weight $(\mathrm{g})$, protein $(\mathrm{g} / \mathrm{kg}$ dry weight $)$, water $(\mathrm{g} / \mathrm{kg}$ wet weight $)$ and fat $(\mathrm{g} / \mathrm{kg}$ dry weight $)$ contents of litters

(Mean values with their standard errors)

\begin{tabular}{|c|c|c|c|c|c|c|}
\hline \multirow[t]{2}{*}{$\begin{array}{l}\text { Group no. }{ }^{*} \ldots \\
n .\end{array}$} & \multicolumn{2}{|c|}{$\begin{array}{c}1 \\
11\end{array}$} & \multicolumn{2}{|c|}{$\begin{array}{c}2 \\
12\end{array}$} & \multicolumn{2}{|c|}{$\begin{array}{c}3 \\
13\end{array}$} \\
\hline & Mean & SE & Mean & SE & Mean & SE \\
\hline Parturition time & 122 & $16 \cdot 1$ & 125 & $15 \cdot 4$ & 127 & $14 \cdot 8$ \\
\hline No. of pups & $11 \cdot 5$ & 0.838 & $12 \cdot 3$ & $0 \cdot 802$ & $12 \cdot 5$ & 0.771 \\
\hline Mean live pup wt & $5 \cdot 718$ & 0.274 & 4.893 & $0 \cdot 262$ & $5 \cdot 129$ & 0.252 \\
\hline Protein & 494 & $23 \cdot 3$ & 521 & $22 \cdot 3$ & 533 & $21 \cdot 5$ \\
\hline Water & 840 & $4 \cdot 22$ & 850 & $4 \cdot 04$ & 845 & $3 \cdot 88$ \\
\hline Fat & 227 & $16 \cdot 37$ & 176 & $15 \cdot 68$ & 186 & 15.06 \\
\hline
\end{tabular}

* Iron and zinc $(\mathrm{mg} / \mathrm{kg})$ contents of the diets: group 1 (control), 45.8, 61 ; group 2, 40.1, 6.9; group 3, $168,7 \cdot 0$.

Table 3. Expt 1. Mean pup iron and zinc contents, and maternal haemoglobin $(\mathrm{Hb}, \mathrm{g} / \mathrm{l})$ and packed cell volume ( $P C V$ ) from mothers given diets of varying $\mathrm{Fe}$ and $\mathrm{Zn}$ contents

(Mean values with their standard errors)

\begin{tabular}{|c|c|c|c|c|c|c|}
\hline \multirow[t]{2}{*}{$\begin{array}{l}\text { Group no.*... } \\
n \ldots\end{array}$} & \multicolumn{2}{|c|}{$\begin{array}{c}1 \\
11\end{array}$} & \multicolumn{2}{|c|}{$\begin{array}{c}2 \\
12\end{array}$} & \multicolumn{2}{|c|}{$\begin{array}{c}3 \\
13\end{array}$} \\
\hline & Mean & SE & Mean & SE & Mean & $\mathrm{SE}$ \\
\hline Mean pup Fe $(\mu \mathrm{g})$ & $247 \cdot 3^{e, f}$ & 15.99 & $199 \cdot 2^{\mathrm{e}}$ & $15 \cdot 31$ & $273 \cdot 8^{\mathrm{f}}$ & $14 \cdot 71$ \\
\hline Mean pup $\mathrm{Zn}(\mu \mathrm{g})$ & $108 \cdot 5^{\mathrm{c}}$ & $5 \cdot 57$ & $83 \cdot 6^{d}$ & $5 \cdot 33$ & $84 \cdot 8^{d}$ & $5 \cdot 12$ \\
\hline Maternal $\mathrm{Hb}(\mathrm{g} / 1)$ & $124^{\mathrm{a}}$ & $3 \cdot 5$ & $130^{\mathrm{ab}}$ & $3 \cdot 4$ & $138^{\mathrm{b}}$ & $3 \cdot 2$ \\
\hline Maternal PCV & $0 \cdot 341^{\mathrm{a}}$ & $0 \cdot 0097$ & $0 \cdot 362^{\mathrm{ab}}$ & 0.0093 & $0 \cdot 380^{\mathrm{b}}$ & $0 \cdot 0089$ \\
\hline
\end{tabular}

* Fe and $\mathrm{Zn}(\mathrm{mg} / \mathrm{kg})$ contents of the diets: group I (control), 45.8, 61; group 2, 40.1, 6.9; group 3, $168,7 \cdot 0$. Mean values in the same horizontal line with different superscript letters were significantly different: a, b $P<0.05$, c, d $P<0.01$, e, $P<0.001$.

were $45 \cdot 8,61 \cdot 0$ for diet $1,40 \cdot 1,6 \cdot 9$ for diet 2 and $168 \cdot 0,7 \cdot 0$ for diet 3 . As shown in Table 2 there were no differences in parturition times, numbers of pups born, mean live pup weight, protein, water or fat contents of litters.

The mean pup Fe and $\mathrm{Zn}$ contents from each group are shown in Table 3 together with maternal $\mathrm{Hb}$ and PCV. There were significant differences between the groups; the control (adequate- $\mathrm{Zn}$ ) group had higher pup $\mathrm{Zn}$ than the low- $\mathrm{Zn}$ groups, the Fe-supplemented group had higher pup Fe than the low-Zn but not the control group, and the Fe-supplemented low- $\mathrm{Zn}$ group had higher maternal $\mathrm{Hb}$ and PCV than the control but not the unsupplemented low- $\mathrm{Zn}$ group. The low- $\mathrm{Zn}$ groups had a greater number of pups showing signs of haemorrhages or deformities. There was only one litter in group 1 with some pups showing signs of haemorrhage, whereas there were five litters in group 2 (one litter containing six dead pups) and four litters in group 3.

\section{Expt 2}

The Fe and $\mathrm{Zn}$ content of the diets is shown in Table 4. The growth curves for the five groups of rats are shown in Fig. 1. Food intakes did not differ between the pregnant animals for each trimester, but they were significantly higher in all pregnant than in non-pregnant 
Table 4. Expt 2. Iron and zinc contents $(\mathrm{mg} / \mathrm{kg})$ of diets

\begin{tabular}{cccc}
\hline \hline Group no. & Fe & $\mathrm{Zn}$ & $\mathrm{Fe}: \mathrm{Zn}$ \\
\hline 1 & $32 \cdot 4$ & $39 \cdot 1$ & 0.8 \\
2 & $70 \cdot 5$ & $40 \cdot 4$ & $1 \cdot 7$ \\
3 & $114 \cdot 6$ & $39 \cdot 1$ & 2.9 \\
& $148 \cdot 3$ & $40 \cdot 0$ & $3 \cdot 7$ \\
\hline
\end{tabular}

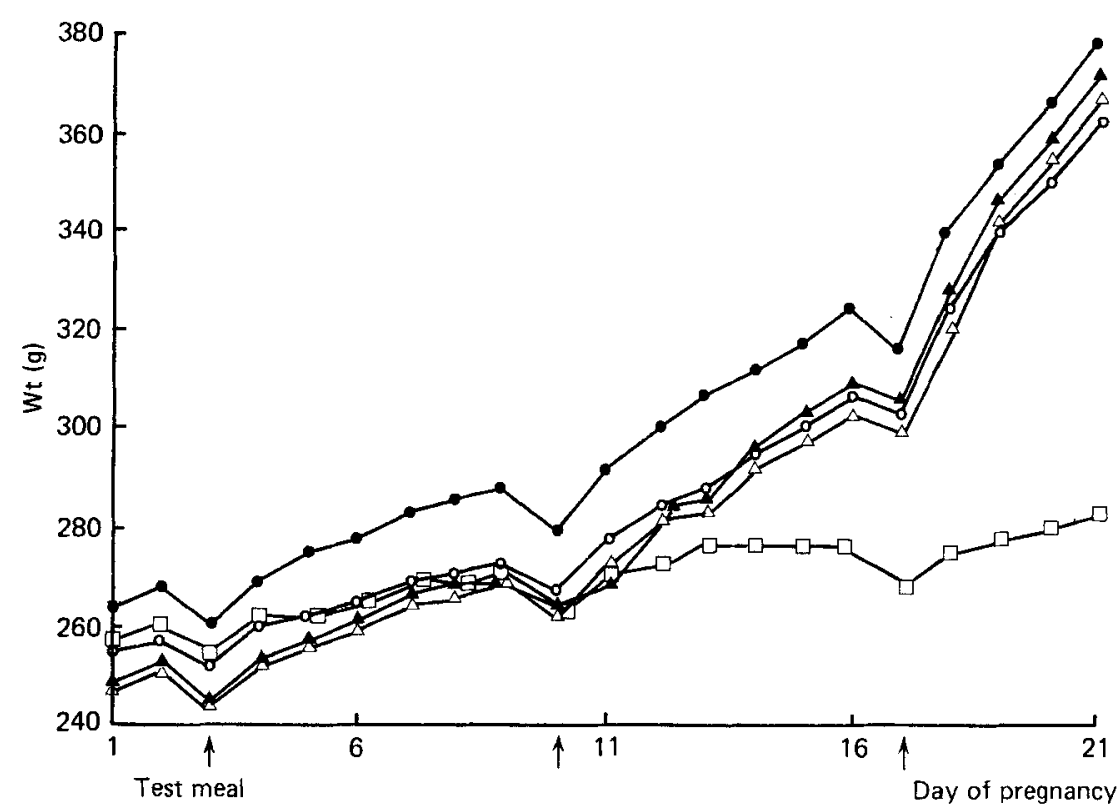

Fig. 1. Expt 2. Growth curves for pregnant rats given diets of varying iron : zinc. Points represent mean values for: (O), group $1(\mathrm{Fe}: \mathrm{Zn} 0.8), n 19 ;(\bullet)$, group 2 (Fe: $\mathrm{Zn} \mathrm{1.7),} n 17 ;(\triangle)$, group 3 (Fe: $\mathrm{Zn} \mathrm{2.9}$ )

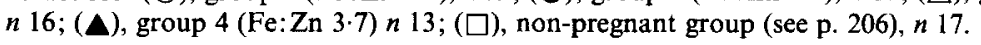

animals during the second week. This difference persisted during the third week in all groups except group 1. Body-weights were lower on the day of the test meals because of the overnight fast.

$\mathrm{Zn}$ retention in the five groups of rats given test meals on days 3,10 and 17 is shown in Fig. 2. Because of small numbers in each group all the non-pregnant animals were grouped together since analysis of the results with the pregnant rats showed no effect of $\mathrm{Fe}: \mathrm{Zn}$ level. Two-way analysis of variance showed a significant $(P<0.001)$ effect of stage of pregnancy on $\mathrm{Zn}$ retention. In all groups retention was highest on day 3 of pregnancy, i.e. the beginning of the first trimester, fell on day 10 and significantly increased on day 17 of pregnancy in all groups except the non-pregnant animals. The latter group absorbed significantly less $\mathrm{Zn}$ from the last test meal than the pregnant animals $(P<0.01)$.

Values for animals killed 24-48 h after giving birth are shown in Table 5. Only animals which had eaten all three test meals were included in the results. There were no differences in numbers of pups surviving or mean pup weight. The amount of ${ }^{65} \mathrm{Zn}$ remaining in the mothers and pups (expressed as a proportion of the amount on day 21 of pregnancy) is also shown. There were no differences between the groups.

The remaining mothers and pups were counted $14 \mathrm{~d}$ after parturition and the ${ }^{65} \mathrm{Zn}$ content 


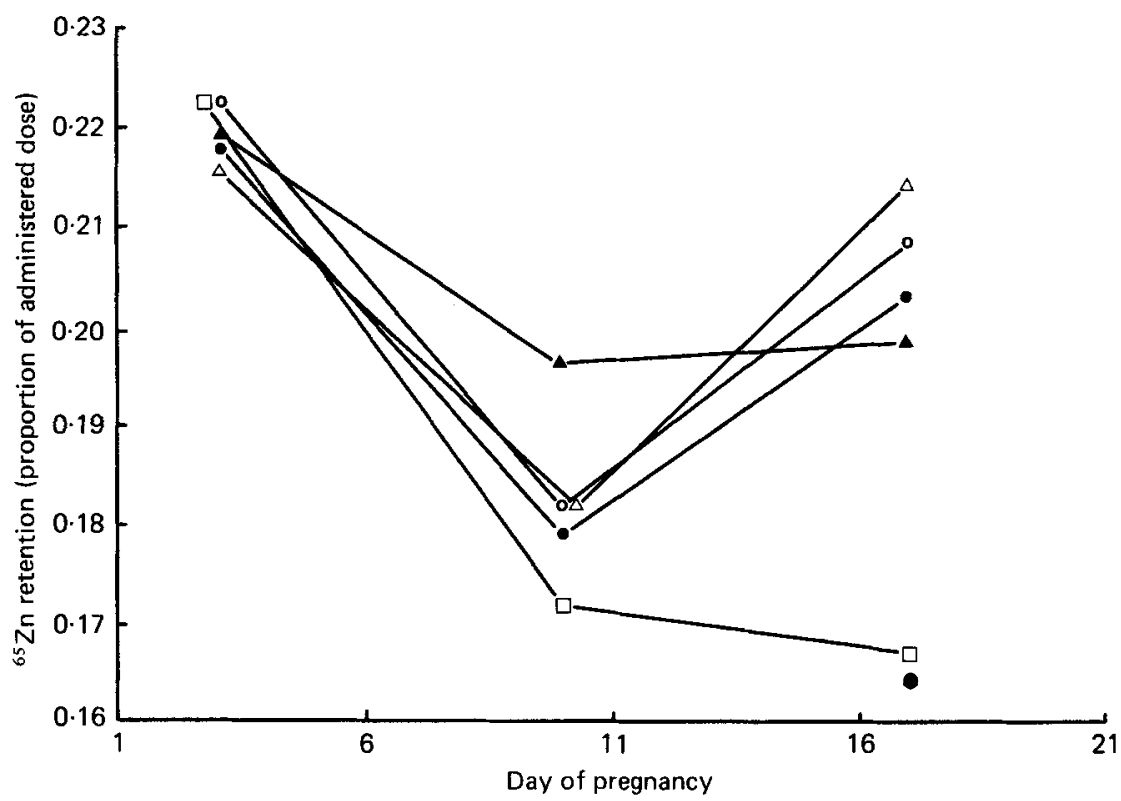

Fig. 2. Expt 2. Zinc retention (proportion of administered dose) by pregnant and non-pregnant rats from $5 \mathrm{~g}$ diet $(40 \mathrm{mg} \mathrm{Zn} / \mathrm{kg}$ ) containing different levels of iron. Points are mean values for each group at each time-point. (O), group $1 ;(\odot)$, group $2 ;(\triangle)$, group $3 ;(\Delta)$, group $4 ;(\square)$, non-pregnant group. Standard errors for differences between the means: (1) at different times for the same group 0.01025 , (2) between different groups 0.01134. *Groups $1-4>$ non-pregnant, $P<0.01$.

Table 5. Expt 2. Mean numbers of pups 24-48 $h$ after birth, mean pup weight $(g)$ and ${ }^{65} \mathrm{Zn}$ in mothers and pups (expressed as proportion of ${ }^{65} \mathrm{Zn}$ in mothers at day 21 of pregnancy) in rats given diets of varying $\mathrm{Fe}: \mathrm{Zn}$

(Mean values with their standard errors)

\begin{tabular}{|c|c|c|c|c|c|c|c|c|c|c|}
\hline \multirow{2}{*}{$\begin{array}{c}\text { Group } \\
\text { no.* }\end{array}$} & & \multirow[b]{2}{*}{$n$} & \multicolumn{2}{|c|}{ No. of pups } & \multicolumn{2}{|c|}{ Mean pup wt } & \multicolumn{2}{|c|}{${ }^{65} \mathrm{Zn}$ in mother } & \multicolumn{2}{|c|}{${ }^{65} \mathrm{Zn}$ in pups } \\
\hline & & & Mean & SE & Mean & SE & Mean & SE & Mean & SE \\
\hline 1 & $(\mathrm{Fe}: \mathrm{Zn} 0.8)$ & 8 & $12 \cdot 3$ & $1 \cdot 10$ & $5 \cdot 71$ & $0 \cdot 26$ & 0.73 & 0.023 & 0.25 & 0.026 \\
\hline 2 & $(\mathrm{Fe}: \mathrm{Zn} 1.7)$ & 8 & $12 \cdot 0$ & $1 \cdot 10$ & 5.93 & $0 \cdot 26$ & 0.73 & 0.023 & $0 \cdot 26$ & 0.026 \\
\hline 3 & $(\mathrm{Fe}: \mathrm{Zn} 2.9)$ & 8 & $12 \cdot 1$ & $1 \cdot 10$ & 5.95 & $0 \cdot 26$ & $0 \cdot 72$ & 0.023 & $0 \cdot 25$ & 0.026 \\
\hline 4 & $(\mathrm{Fe}: \operatorname{Zn~} 3.7)$ & 6 & 10.5 & $1 \cdot 27$ & 6.05 & 0.30 & 0.76 & 0.017 & 0.23 & 0.03 \\
\hline
\end{tabular}

* For details, see Table 4.

is shown in Fig. 3 together with the ${ }^{65} \mathrm{Zn}$ content of mothers and pups $24-48 \mathrm{~h}$ after birth. Three animals from each group were also counted 21 and $24 \mathrm{~d}$ after birth as shown in Fig. 3. Results are again expressed as a proportion of the amount of ${ }^{65} \mathrm{Zn}$ on day 21 of pregnancy. The three animals selected from each group were representative of the group as a whole since the mean ${ }^{65} \mathrm{Zn}$ content of each subgroup on day 14 was similar to that of the whole group.

Analysis of variance showed there was no effect of diet on the proportion of ${ }^{65} \mathrm{Zn}$ retained at any one time-period, but there was a significant effect of time in both mothers and pups $(P<0.001)$ from day 1 until day 14 after birth. After this time the ${ }^{65} \mathrm{Zn}$ content of the pups did not appear to increase but the maternal ${ }^{65} \mathrm{Zn}$ continued gradually to fall. 


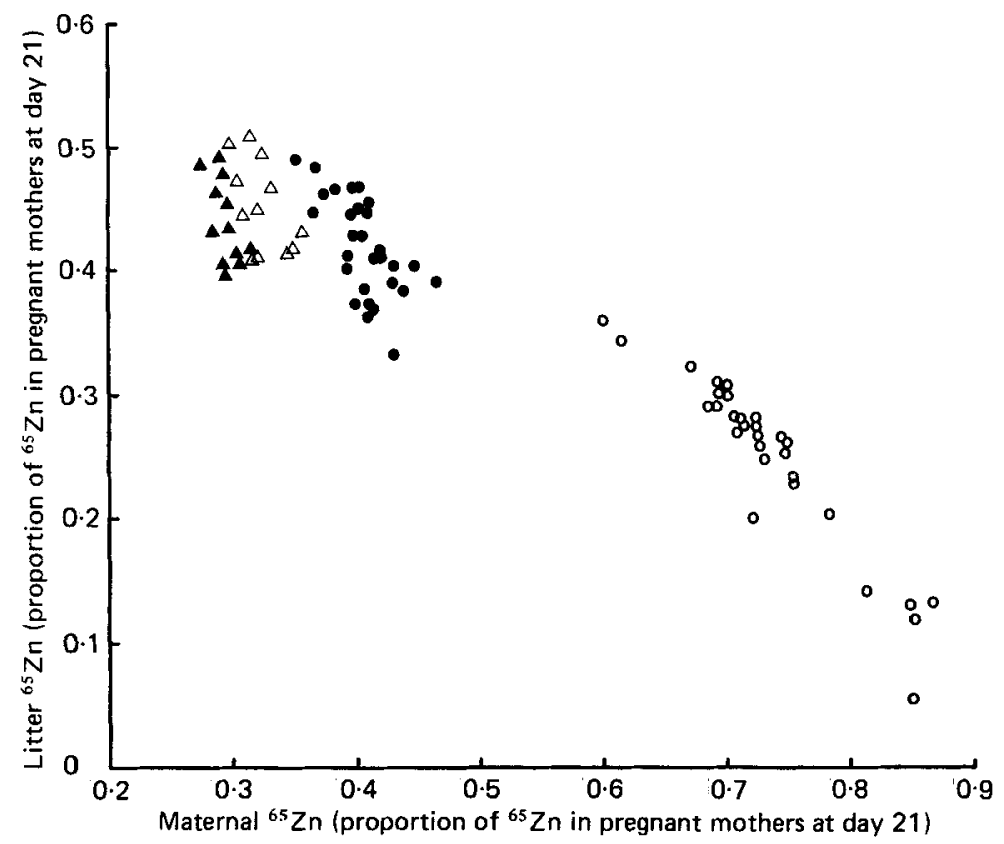

Fig. 3. Expt 2. Distribution of ${ }^{65} \mathrm{Zn}$ in mothers and litters (proportion of ${ }^{65} \mathrm{Zn}$ in pregnant mothers at day 21$)(O) 2448 \mathrm{~h},(O) 14 \mathrm{~d},(\Delta) 21 \mathrm{~d}$ and $(\Delta) 24 \mathrm{~d}$ after birth in rats given diets of varying iron: $\mathrm{Zn}$, expressed as a proportion of ${ }^{65} \mathrm{Zn}$ in mothers on day 21 of pregnancy.

\section{DISCUSSION}

The administration of a severely-Zn-deficient diet $(<1 \mathrm{mg} / \mathrm{kg}$ ) during pregnancy in the rat results in $\mathrm{Zn}$-deficient pups which are significantly smaller, fewer in number and have a greater number of abnormalities than controls (Masters et al. 1983). In Expt 1, when mothers were given a diet slightly higher in $\mathrm{Zn}(7 \mathrm{mg} / \mathrm{kg})$ such that food intakes were not altered, the pups also had a significantly reduced $\mathrm{Zn}$ content $(P<0.01)$ but were no fewer in number. The addition of $\mathrm{Fe}$ to the low- $\mathrm{Zn}$ diet produced pups that were no different in weight from the control or the low-Zn groups. It was noted, however, that some of the low-Zn mothers were neglecting their litters, leaving them scattered round the cage and not feeding them.

As found previously (Fairweather-Tait et al. 1984), and shown in Table 3, mothers given Fe supplements during pregnancy had a significantly $(P<0.05)$ higher $\mathrm{Hb}$ and PCV than controls. This increase in maternal $\mathrm{Fe}$ status was reflected in the litter since mean pup $\mathrm{Fe}$ content was significantly $(P<0.001)$ higher in the Fe-supplemented than unsupplemented low-Zn groups.

There were no differences in mean pup $\mathrm{Zn}$ levels in the Fe-supplemented and unsupplemented low-Zn groups. Both diets produced pups with lower $\mathrm{Zn}$ content $(P<0.01)$ than the control diet. As far as composition of the pups is concerned (see Table 2) there were no differences in water, fat or protein contents.

The diets used in Expt 1 contained very little $\mathrm{Zn}(7 \mathrm{mg} / \mathrm{kg})$ in order to test the $\mathrm{Fe}-\mathrm{Zn}$ interaction effects under extreme conditions. It could be assumed that the $\mathrm{Zn}$ level was so low that any interaction with $\mathrm{Fe}$ would not be measurable. Moreover it is unlikely that diets of such low $\mathrm{Zn}$ content would be consumed under normal circumstances, and it was decided in Expt 2 to use diets of higher $\mathrm{Zn}$ content $(40 \mathrm{mg} / \mathrm{kg})$.

Solomons et al. (1983) have shown that $\mathrm{Fe}$ reduces plasma uptake of $\mathrm{Zn}$ at $\mathrm{Fe}: \mathrm{Zn}$ of 
$2: 1$, particularly with ferrous-Fe. The diets used in Expt 2 contained $\mathrm{Fe}: \mathrm{Zn}$ of $0 \cdot 8-3 \cdot 7$, with adequate $\mathrm{Fe}\left(\mathrm{as}_{\mathrm{FeSO}}\right.$ ) and $\mathrm{Zn}$ levels. $\mathrm{Zn}$ retention was measured from these diets at the beginning of each trimester and also in non-pregnant rats on the same diet. It was found that the addition of $\mathrm{Fe}$ had no effect on $\mathrm{Zn}$ retention at any time-period but that the pregnancy itself did influence uptake of $\mathrm{Zn}$. Fig. 2 shows a fall in $\mathrm{Zn}$ retention from day 3 to day 10 of pregnancy and then a rise on day 17 of pregnancy. Examination of the values from non-pregnant animals clearly indicate that $\mathrm{Zn}$ retention was also significantly higher from the first meal than from the other two meals. However, retention from the first meal was similar to that for the pregnant animals which might be expected assuming that in the very early stages of pregnancy requirements for $\mathrm{Zn}$ did not substantially increase.

Fig. 1 shows that the pregnant animals only started to gain more weight than the non-pregnant animals after day 11 of pregnancy. The difference between the first meal and the other two meals can be explained by considering the diets that the animals were consuming before the test meal. All the rats were given the control, semi-synthetic diet for $10 \mathrm{~d}$ before the experiment began and this contained $60 \mathrm{mg} \mathrm{Zn} / \mathrm{kg}$. Once mated they were given diets containing $40 \mathrm{mg} \mathrm{Zn} / \mathrm{kg}$ with varying Fe levels, and $\mathrm{Zn}$ retention measured $36 \mathrm{~h}$ after the changeover. There is evidence that $\mathrm{Zn}$ uptake by the mucosa is increased in response to reduced $\mathrm{Zn}$ status (Menard \& Cousins, 1983) and we believe that $\mathrm{Zn}$ retention from the first test meal was temporarily raised because of the recent change of diet, and that the $\mathrm{Zn}$ retention results from the second test meal were more representative of the animals' ability to absorb $\mathrm{Zn}$ from the diet given throughout the experimental period. Results from the third test meal show an increase in $\mathrm{Zn}$ retention in the pregnant but not the non-pregnant rats, presumably in response to increased requirement.

There were no differences between the four groups in numbers of pups, mean pup weight, or proportion of ${ }^{65} \mathrm{Zn}$ in the mothers and pups $24-48 \mathrm{~h}$ after birth. It can therefore be concluded again that $\mathrm{Fe}$ did not influence $\mathrm{Zn}$ retention from the diet or its metabolism during pregnancy. The percentage of ${ }^{65} \mathrm{Zn}$ transferred from mothers to pups was very high; about $25 \%$ of total body ${ }^{65} \mathrm{Zn}$ was passed from the mothers to the pups. This emphasized the importance of dietary $\mathrm{Zn}$ during pregnancy, since it must initially enter a labile pool in the body and then be transferred to the fetuses in preference to the $\mathrm{Zn}$ already in the body which is presumably less-easily mobilized. This is in agreement with Williams et al. (1977) who showed that there was negligible accumulation of $\mathrm{Zn}$ by the mothers during pregnancy in the rat.

The ${ }^{65} \mathrm{Zn}$ content of the mothers and pups during lactation (Fig. 3) showed a wide scatter at the first time-point, i.e. $24-48 \mathrm{~h}$ after birth. As expected, for each animal the sum of ${ }^{65} \mathrm{Zn}$ in the mother and ${ }^{65} \mathrm{Zn}$ in the litter was nearly $100 \%$ of the ${ }^{65} \mathrm{Zn}$ content of the pregnant mothers on day 21 of pregnancy. The ${ }^{65} \mathrm{Zn}$ content of the mothers decreased quickly at a constant rate and it was estimated that it would fall to zero in about $40 \mathrm{~d}$ if the rate of decrease did not change. The ${ }^{65} \mathrm{Zn}$ content of the litters increased but at a slower rate than the fall in the mothers and levelled out by about day 20. In contrast Williams et al. (1977) showed that the accretion rate of $\mathrm{Zn}$ reached a 'plateau' value when the pups were only $6 \mathrm{~d}$ old. It has been suggested by Moser \& Reynolds (1983) that the controlling factor for $\mathrm{Zn}$ concentration in breast milk is hormonal since they found no correlation between $\mathrm{Zn}$ intake and $\mathrm{Zn}$ concentration in the milk. The variability in the maternal ${ }^{65} \mathrm{Zn}$ decreased rapidly, the standard deviation decreasing linearly with the mean. Extrapolating this relationship implied that the standard deviation became zero at a mean of $18 \%$, as if this level of ${ }^{65} \mathrm{Zn}$ were a constant 'base level' for all mothers. The variability in litter ${ }^{65} \mathrm{Zn}$ follows that of the mother's ${ }^{65} \mathrm{Zn}$ over time, thus the standard deviation of the litter ${ }^{65} \mathrm{Zn}$ depends not on its own mean but on the mean of the mother's ${ }^{65} \mathrm{Zn}$. As far as $\mathrm{Fe}: \mathrm{Zn}$ in the diet is concerned, there were no effects of diet on ${ }^{65} \mathrm{Zn}$ transfer at any one time-period. 
In conclusion, it would appear that dietary Fe does not affect the uptake or metabolism of $\mathrm{Zn}$ in pregnant and lactating rats from either very low $(7 \mathrm{mg} / \mathrm{kg})$ or adequate $(40 \mathrm{mg} / \mathrm{kg})$ $\mathrm{Zn}$ diets. Pregnancy itself influences $\mathrm{Zn}$ metabolism as shown by the increase in $\mathrm{Zn}$ retention at the beginning of the third trimester of pregnancy compared with non-pregnant animals. A high percentage $(25 \%)$ of the ${ }^{65} \mathrm{Zn}$ acquired during pregnancy was transferred to the pups by the time they were $48 \mathrm{~h}$ old, and decreasing amounts continued to be transferred up until day 20 of lactation by which time there was no further increase in pup ${ }^{65} \mathrm{Zn}$ content. The importance of dietary $\mathrm{Zn}$ as a labile pool to be used for the developing fetus during the fast-growth period is demonstrated by the present study.

The authors would like to thank Mrs V. Payne and Mrs J. Cooke for assistance with the animals, Mrs Z. Piper for technical assistance, Mr M. Gee for AAS analyses, Mrs S. Ring and $\mathrm{Mr} \mathrm{J}$. Franklin for help with the statistics and computer programs.

\section{REFERENCES}

Fairweather-Tait, S. J., Payne, V. \& Williams, C. M. (1984). British Journal of Nutrition 52, $79-86$.

Fairweather-Tait, S. J. \& Wright, A. J. A. (1984), British Journal of Nutrition 51, 185-191.

Lowry, O. H., Rosebrough, N. J., Farr, A. L. \& Randall, R. J. (1951). Journal of Biological Chemistry 193, 265-275.

Masters, D. G., Keen, C. L., Lönnerdal, B. \& Hurley, L. S. (1983). Journal of Nutrition 113, $1448-1451$.

Meadows, N. J., Ruse, W., Smith, M. F., Day, J., Keeling, P. W. N., Scopes, J. W., Thompson, R. P. H. \& Bloxam, D. L. (1981). Lancet ii, 1135-1137.

Menard, M. P. \& Cousins, R. J. (1983). Journal of Nutrition 113, 1434-1442.

Moser, P. B. \& Reynolds, R. D. (1983). American Journal of Clinical Nutrition 38, 101-108.

Snedecor, G. W. (1957). Statistical Methods, 5th ed., p. 287. Ames, Iowa: Iowa State University Press.

Solomons, N. W., Pineda, O., Viteri, F. \& Sandstead, H. H. (1983). Journal of Nutrition 113, 337-349.

Williams, R. B., Davies, N. T. \& McDonald, I. (1977). British Journal of Nutrition 38, 407-416.

Williams, R. B., Demertzis, P. \& Mills, C. F. (1973). Proceedings of the Nutrition Society 32, 3A-4A. 